\title{
Simazine, a triazine herbicide, disrupts swine granulosa cell functions
}

\author{
Francesca Grasselli, Simona Bussolati, Roberto Ramoni, Stefano Grolli, Giuseppina Basini ${ }^{1}$
}

Dipartimento di Scienze Medico-Veterinarie, Università di Parma, 43126 Parma, Italy.

\begin{abstract}
The triazine herbicide simazine is a pesticide commonly detected in surface and ground waters, although banned in most European countries since 2004. Concerns for humans and animal health result from its potential endocrine disrupting action, that can lead to reproductive disorders. The present in vitro study was undertaken to study simazine effects on swine granulosa cell function, namely cell viability, proliferation, steroidogenesis and NO production. Moreover, the ability of this substance to interfere with the angiogenetic process, a crucial event in reproductive function, was taken into account. Our data document that simazine treatment, at 0.1 or $10 \mu \mathrm{M}$ concentration levels, stimulates granulosa cell proliferation and viability and impairs steroidogenesis, increasing in particular progesterone production. In addition, the in vitro angiogenesis bioassay revealed a significant simazine stimulatory effect on immortalized porcine Aortic Endothelial Cell proliferation. Collectively, these results show that simazine can display disruptive effects on ovarian cell functional parameters, possibly resulting in reproductive dysfunction. This hypothesis is also supported by the observed pro-angiogenetic properties of this herbicide, as already suggested for different endocrine disruptors.
\end{abstract}

Keywords: simazine, endocrine disruptor, swine granulosa cells, ovarian function, angiogenesis.

\section{Introduction}

Simazine belongs to the triazine family, a group of chemicals which are widely employed as broad-spectrum herbicides due to their inhibition of electron transfer in photosynthesis (Qian et al., 2014). Owing to their effectiveness, these herbicides have been heavily used in the United States, Europe and Australia for more than 50 years (Breckenridge et al., 2016). Compared to other herbicides, triazines are more soluble in water and they can leach from soils to surface and ground waters; thus, contamination of drinking water can raise concerns both for human and animal health.

Atrazine and simazine have gained attention in the field of water policy since 2001 (European Parliament and Council of European Union, 2001). In most European countries their registrations were canceled (Commission of the European Communities, 2004a and b) due to their persistence in the environment and mobility in soil and ground water (Thurman et al., 1992). In particular, simazine represents the second most commonly detected pesticide in surface and ground waters in different regions worldwide (Sai et al., 2015).

Although in Italy it has been banned from use from 2005, the recent 2016 Report of Istituto Superiore per la Protezione e la Ricerca Ambientale (ISPRA) still reported the presence of simazine in both surface and ground water (ISPRA Rapporto nazionale pesticidi nelle acque), especially in the river Po valley. In the U.S., where triazine herbicides are still used, atrazine and simazine have been reported above the maximum admitted contaminant levels in groundwater (USEPA, 2006).

Due to structural similarity to atrazine, simazine and other major chlorometabolites have been classified as a Common Mechanism Group with disrupting effects on hypothalamic-pituitary-gonadal axis (USEPA, 2006). However, to date only few studies have focused on simazine potential adverse health effects and further examinations are therefore required.

Concerns have been raised about the endocrine disrupting effects of triazines and their chlorometabolites, whose adverse effects have been documented in different species. In particular, both atrazine and simazine affects the hypothalamicpituitary-gonadal axis inducing variations in ovulatory cycles and constant estrus in female rats (Cooper et al., 2000). Moreover, chlorotriazines have been involved in the increased risk of mammary tumors resulting from continuous estrogen stimulation of mammary gland (Stevens et al., 1994; Fuhrman et al., 2012). In the mouse, Park et al. (2014) recently documented impaired development and growth in offsprings resulting from maternal exposure to low levels of simazine during gestation. Increased apoptosis and decreased proliferation in mouse ovaries have also been shown (Park et al., 2014), as well as a significant delay of the onset of puberty in rats after simazine treatment (Zorrilla et al., 2010).

Even if in vitro studies have highlighted timeand dose-dependent effects on steroidogenesis in murine Leydig cell lines (Forgacs et al., 2013) and a disruption on relaxin signaling and nitric oxide production in human granulosa cells (Park et al., 2016), a comprehensive understanding of simazine effects on ovarian physiology is lacking. Granulosa cells represent a valuable model to investigate ovarian function: they are essential for ovarian follicle growth, steroidogenesis, oocyte survival and nourishment. Moreover, they are an interesting example of angiogenesis; they are the unique site of physiological neovascularization in the adult that occurs cyclically in the ovary, driving the normal development and growth of ovarian follicles (Basini et al., 2008). 
This in vitro study was set up to verify if simazine can display disrupting effects on swine granulosa cell function, namely cell viability, proliferation, steroidogenesis and NO production.

By means of a previously validated threedimensional in vitro angiogenesis assay (Basini et al., 2016), we also verified the ability this substance to interfere with the angiogenetic process, which represents a crucial event involved in ovarian follicles physiological development.

\section{Materials and Methods}

All reagents were obtained from Sigma (St. Louis, MO, USA) unless otherwise specified.

\section{Granulosa cell collection}

Swine ovaries were collected at a local slaughterhouse from Large White cross-bred gilts, parity $=0$. The stage of the cycle was unknown. Follicles were classified on a dimension-based fashion (Basini et al., 2008). The ovaries were placed into cold PBS $\left(4^{\circ} \mathrm{C}\right)$ supplemented with penicillin (500 IU/mL), streptomycin (500 $\mu \mathrm{g} / \mathrm{mL})$ and amphotericin B (3.75 $\mu \mathrm{g} / \mathrm{mL})$, maintained in a freezer bag and transported to the laboratory within $1 \mathrm{~h}$. After a series of washings with PBS and ethanol 70\%, granulosa cells were aseptically harvested by aspiration of large follicles $(>5 \mathrm{~mm})$ with a 26-gauge needle and released in medium containing heparin $(50 \mathrm{IU} / \mathrm{mL})$, centrifuged for pelleting and then suspended in 0.9 percent (W/V) prewarmed ammonium chloride at $37^{\circ} \mathrm{C}$ for 1 min to remove red blood cells. Cell number and viability were estimated using a haemocytometer under a phase contrast microscope after vital staining with trypan blue $0.4 \%$ of an aliquot of the cell suspension. Cells were seeded in culture medium (CM) represented by DMEM/Ham's F12 (Gibco, Grand Island, NY, USA) supplemented with sodium bicarbonate (2.2 $\mathrm{mg} / \mathrm{mL}$ ), bovine serum albumin (BSA 0.1\%), penicillin (100 IU/mL), streptomycin $(100 \mu \mathrm{g} / \mathrm{mL})$, amphotericin B $(2.5 \mu \mathrm{g} / \mathrm{mL})$, selenium (5 ng/mL) and transferrin (5 $\mu \mathrm{g} / \mathrm{mL})$. Once seeded, cells were incubated in the presence or absence of simazine $(0.1$ or $10 \mu \mathrm{M})$. The tested concentrations were chosen on the basis of the expected ovarian concentrations after simazine exposure (Forgacs et al., 2013). Ethanol was used as the carrier solvent and its final concentration was less than $0.1 \%$ $\mathrm{v} / \mathrm{v}$, a level that has no effects on the examined parameters. Cells were then maintained for $48 \mathrm{~h}$ at $37^{\circ} \mathrm{C}$ under humidified atmosphere $\left(5 \% \mathrm{CO}_{2}\right)$. This procedure was identical for all experiments performed in this study.

\section{Granulosa cell viability}

Intracellular ATP level was measured using a luminescence ATP detection assay (ATPlite Perkin Elmer Inc., Waltham, MA, USA) according to the supplier's instruction. ATP is a marker for cell viability because it is present in all metabolically active cells and its concentration declines very rapidly when the cells undergo either necrosis or apoptosis. Briefly, each lyophilized substrate solution vial was reconstituted with $5 \mathrm{~mL}$ substrate buffer and shaken gently until homogenous, then aliquoted and stored at $-20^{\circ} \mathrm{C}$. Similarly, $1170 \mu \mathrm{L}$ of sterile distilled water was added to a lyophilized ATP standard vial to get a final10 $\mathrm{mM}$ concentration level. Then, six different ATP dilutions $\left(10^{-3}-10^{-8} \mathrm{M}\right.$ concentration range) were prepared in distilled water and stored at $-20^{\circ} \mathrm{C}$. Granulosa cells $\left(2 \times 10^{5}\right.$ cells per $200 \mu \mathrm{L} \mathrm{CM} /$ well) were grown in 96well microplates and incubated for $48 \mathrm{~h}$ in the presence or absence of simazine $(0.1$ or $10 \mu \mathrm{M})$. For the ATP assay, all reagents (substrate solution, ATP dilution series, and mammalian cell lysis solution) were equilibrated at room temperature. For the ATP standard solutions, $100 \mu \mathrm{L}$ culture media/well were placed into a 96-well plate. Then $50 \mu \mathrm{L}$ of mammalian cell lysis solution which stabilize the ATP were added; $10 \mu \mathrm{L}$ from each ATP dilution series were added to the well containing only culture media and the microplate was shaken for $5 \mathrm{~min}$ on an orbital shaker at $700 \mathrm{rpm}$ at room temperature. Finally, $50 \mu \mathrm{L}$ of the substrate solution was added, and the microplate was shaken again for $5 \mathrm{~min}$ at $700 \mathrm{rpm}$. The plate was covered with an adhesive seal, dark-adapted for $10 \mathrm{~min}$ and luminescence was measured using a luminescence microplate reader (Multilabel Counter Victor, Perkin Elmer, Boston, USA). The ATP standard curve was obtained by plotting the luminescence signal of the different ATP dilutions versus the ATP concentrations. The signal for unknown sample was determined obtained by linear regression analysis.

\section{Granulosa cell proliferation}

$10^{4}$ cell/well were seeded in 96-well plates in $200 \mu \mathrm{L} \quad \mathrm{CM}$ and treated with the simazine concentrations as above indicated. Cell proliferation was evaluated by DELFIA 5-bromo-2'-deoxyuridine (BrdU) incorporation assay test (Roche, Mannheim, Germany). Briefly, after $44 \mathrm{~h}$ of incubation in the presence or absence of treatments, $20 \mu \mathrm{L}$ BrdU were added to each well, then culture media were removed and a DNA denaturating solution was added in order to improve the accessibility of the incorporated BrdU for antibody detection. Thereafter, $100 \mu \mathrm{L}$ anti-BrdU antibody solution were added to each well. After a $1.5 \mathrm{~h}$ incubation at room temperature, $200 \mu \mathrm{l}$ of DELFIA inducer were added and fluorescence emission were recorded by means of Victor. To quantify viable cell number, the fluorescence emission level of each sample was related to a standard curve prepared by culturing, in quintuplicate, granulosa cells at different plating densities (from $10^{3}$ to $10^{5} / 200 \mu \mathrm{L}$ ) for $48 \mathrm{~h}$. The curve was repeated in four different experiments. The relationship between cell number and absorbance was linear $(r=0.92)$. Cell number/well was estimated from the resulting linear regression equation. The assay detection limit was $10^{3}$ cell/well and the variation coefficient was less than $5 \%$. 


\section{Steroid production}

$10^{4}$ cells/well were seeded in 96-well plates in $200 \mu \mathrm{L}$ CM. Since androgens are needed for estradiol synthesis by granulosa cells, CM was supplemented with androstenedione (28 ng/mL) (Basini and Tamanini, 2000) in order to support biosynthetic pathway. Cells were incubated for $48 \mathrm{~h}$ in the presence or absence of simazine $(0.1$ or $10 \mu \mathrm{M})$. Culture media were then collected, frozen and stored at $-20^{\circ} \mathrm{C}$ until progesterone (P4) and $17 \beta$ estradiol (E2) determination by validated RIAs (Grasselli et al., 1993).

P4 assay sensitivity and ED50 were 0.24 and 1 $\mathrm{nmol} / \mathrm{L}$, respectively; E2 assay sensitivity and ED50 were 0.05 and $0.2 \mathrm{nmol} / \mathrm{L}$. The intra- and inter-assay coefficients of variation were less than $12 \%$ for both assays.

\section{NO production}

$10^{5}$ cells/200 $\mu \mathrm{l}$ CM were seeded in 96-well plates and incubated for $48 \mathrm{~h}$ in the presence or absence of simazine $(0.1$ or $10 \mu \mathrm{M})$. NO was assessed by measuring nitrite levels in culture media by the microplate method based on the formation of chromophore after reaction with Griess reagent, which was prepared fresh by mixing equal volumes of stock A (1.0\% W/V sulfanilamide, $5.0 \% \mathrm{~W} / \mathrm{V}$ phosphoric acid in water) and stock B $(0.1 \% \mathrm{~W} / \mathrm{V} \mathrm{N}$-[naphthyl] ethylenediamine dihydrochloride in water) (Dong and Yallampalli, 1996) solutions. After incubation with Greiss reagent the absorbance was determined with the Victor Reader using a $540 \mathrm{~nm}$ against $620 \mathrm{~nm}$ filter. A calibration curve ranging from 0.39 to $25 \mu \mathrm{M}$ was prepared by diluting sodium nitrite in culture medium.

The three-dimensional in vitro angiogenesis assay

The immortalized porcine aortic endothelial cell line (AOC) used in the experiments was kindly provided by Prof. Jose Yélamos (Hospital Universitario Virgen de la Arrixaca, El Palmar, 30120 Murcia, Spain). The cells were used at $13^{\circ}$ passage, grown in Medium 199 (containing Earle's salts and L-glutamine) supplemented with sodium bicarbonate $(2.2 \mathrm{mg} / \mathrm{mL})$, penicillin (100 IU / mL), streptomycin (100 mg / mL), amphotericin B (2.5 mg / mL) and 20\% W/V FBS (Fetal Bovine Serum) (GIBCOTM, Invitrogen Corporation, $\mathrm{UK}$ ) and incubated at $37^{\circ} \mathrm{C}$ in a humidified atmosphere $\left(5 \% \mathrm{CO}_{2}\right)$.

\section{Fibrin gel angiogenesis assay}

The model used to study vascular development (Grasselli et al., 2003) was prepared using AOC grown on dextran beads coated by denatured collagen from porcine skin (citodex-3 microcarrier beads, MC), included in a gelatinous matrix of fibrin. The first stage of gel preparation involves the adhesion of cells to MC; to this, $1.25 \mathrm{mg}$ of MC were incubated for 3 hours at $37^{\circ} \mathrm{C}$ with $1.5 \mathrm{~mL}$ of sterile PBS in order to achieve optimum hydration. After a first washing with sterile PBS and a second one with Medium 199, the MC were put into a flask with $5 \mathrm{~mL}$ culture medium, and AOC $\left(5 \times 10^{5}\right)$ were added. The flask was then incubated overnight at $37^{\circ} \mathrm{C}$, to allow cell adhesion on $\mathrm{MC}$ surface. Then, fibrin gels were prepared in 12 well plates, adding to each well, in the following order: 873 $\mu \mathrm{l}$ of a fibrinogen solution $(1 \mathrm{mg} / \mathrm{mL} \mathrm{PBS}), 20 \mu \mathrm{L}$ of suspension of AOC coated MC, $128 \mu \mathrm{L}$ of thrombin (5 U/mL). Fibrin gel polymerization was obtained by incubation for $30 \mathrm{~min}$ at $37^{\circ} \mathrm{C}$, followed by an 1 hour balancing step with $2 \mathrm{~mL}$ of Medium 199. Thereafter, the medium was removed with an insulin syringe and replaced by Medium 199 + 20\% FBS, containing simazine $(0.1$ or $10 \mu \mathrm{M})$. After 48 hours, media and treatments were renewed and the plates were incubated for additional $48 \mathrm{~h}$. Endothelial buds proliferation starting from MC was quantified through the software for image processing, Scion Image Beta 4:02 (Scion Corporation, MA, USA, http://rsb.info.nih.gov/nihimage). After 48 and 96 hours of incubation five photographic images of each gel were acquired, each containing two or three MC; images were then converted to grayscale, reduced by $50 \%$ (Paintbrush Software, MS Office) and saved as 24-bit Bitmap, compatible with the Scion software. The measurements, in pixels, were made by drawing the perimeter of the area occupied by the AOC. The validity of this method of quantification of AOC proliferation was confirmed by evaluating the correlation between the area covered by the AOC in fibrin gel and the number of cells actually present in the same area (Basini et al. 2008).

\section{Statistical analysis}

Each experiment was repeated at least 6 times with 6 replicates for each treatment. Experimental data are presented as mean \pm SEM; statistical differences were calculated with analysis of variance using the Statgraphics package (STSC Inc., version 5.1, Rockville, MD, USA). When significant differences were found, means were compared by Scheffè's F test. $\mathrm{P}$ values $<0.05$ were considered to be statistically significant.

\section{Results}

\section{Effects on granulosa cell viability and proliferation}

ATP detection assay has shown that simazine is effective $(\mathrm{P}<0.05)$ in stimulating granulosa cell viability (Figure 1). The two concentrations tested displayed similar effects (Figure 1)

Granulosa cell proliferation was significantly $(\mathrm{P}<0.05)$ increased by simazine, without remarkable differences between the two concentrations (Figure 2). 


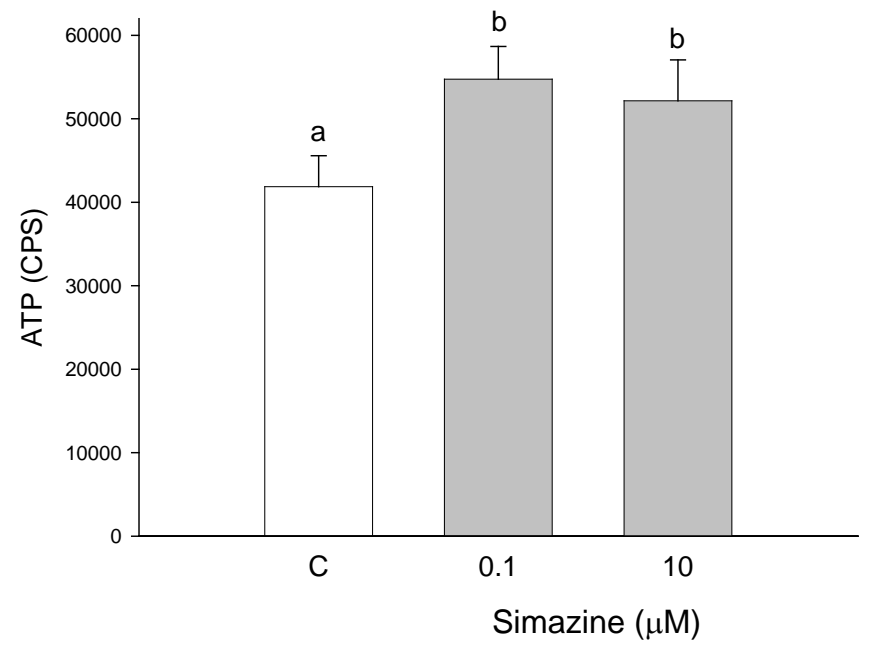

Figure 1 . Effect of the $48 \mathrm{~h}$ treatment with simazine $(0.1$ or $10 \mu \mathrm{M})$ on ATP production by granulosa cells collected from large $(>5 \mathrm{~mm})$ follicles. Data represent the mean \pm SEM of six replicates/treatment repeated in six different experiments. Different letters indicate a significant difference $(\mathrm{P}<0.05)$ among treatments as calculated by ANOVA and Scheffè' $F$ test.

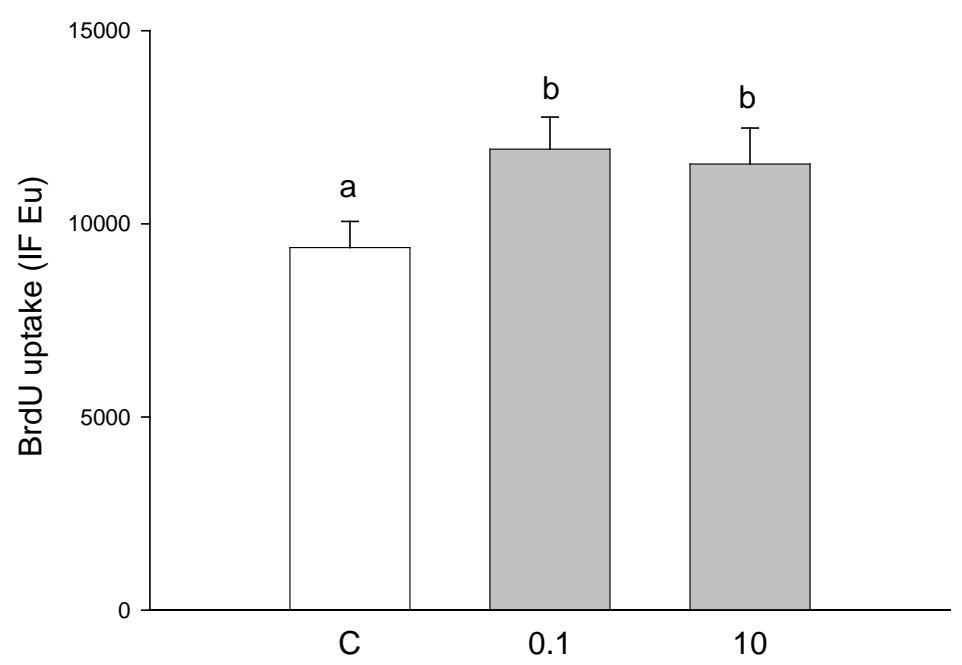

Figure 2. Effect of the $48 \mathrm{~h}$ treatment with simazine $(0.1$ or $10 \mu \mathrm{M})$ on BrdU uptake in granulosa cells collected from large $(>5 \mathrm{~mm})$ follicles. Data represent the mean \pm SEM of six replicates/treatment repeated in six different experiments. Different letters indicate a significant difference $(\mathrm{P}<0.05)$ among treatments as calculated by ANOVA and Scheffè' F test.

\section{Effects on granulosa cell steroidogenesis}

As for steroid production, simazine did not modify estradiol levels as compared to controls (Figure 3a), while progesterone production was stimulated only in granulosa cells incubated with $10 \mu \mathrm{M}$ simazine (P < 0.05; Figure 3b).

\section{Effects on granulosa cell NO production}

Neither 0.1 nor $10 \mu \mathrm{M}$ simazine displayed modulatory effects on NO production by granulosa cells (data not shown).

\section{Effects on AOC growth}

AOC incubated with simazine showed a higher growth rate as compared to controls ( $\mathrm{P}<0.01)$, both after $48 \mathrm{~h}$ and $96 \mathrm{~h}$ of incubation. The two different simazine concentrations displayed similar effects (Figure 4; Panel I a and b; Figure 4 Panel II). 

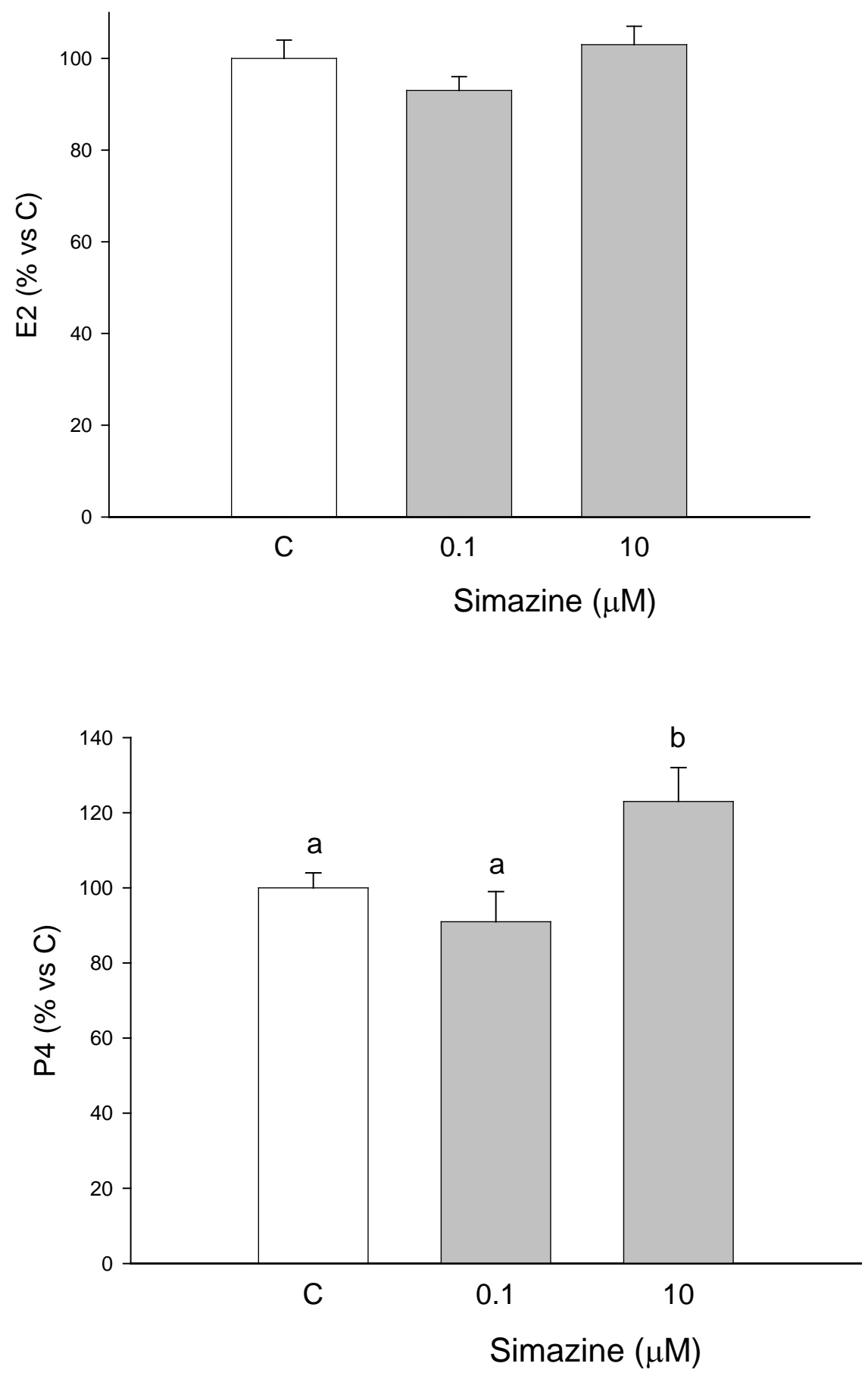

Figure 3. Effect of the $48 \mathrm{~h}$ treatment with simazine (0.1 or $10 \mu \mathrm{M})$ on E2 (A) or P4 (B) output by granulosa cells collected from large $(>5 \mathrm{~mm})$ follicles. Data represent the mean \pm SEM of six replicates/treatment repeated in six different experiments. Different letters indicate a significant difference $(\mathrm{P}<0.05)$ among treatments as calculated by ANOVA and Scheffè' F test. 
I

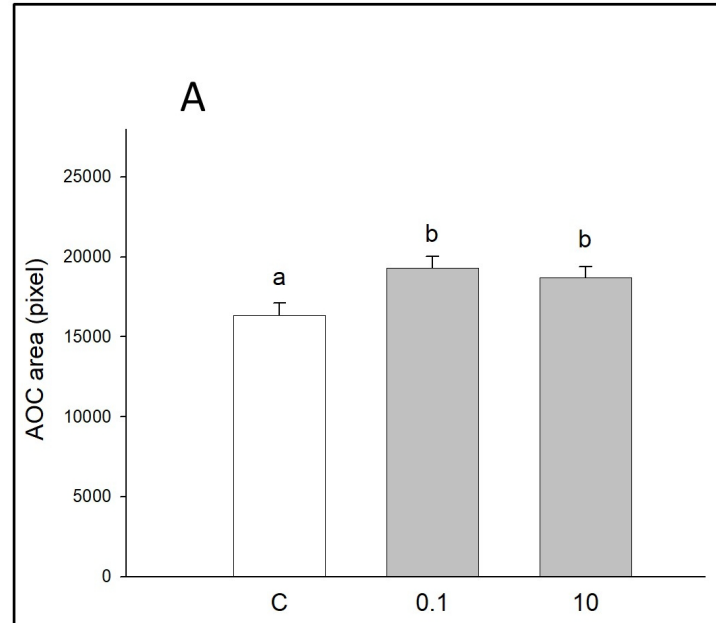

Simazine $(\mu \mathrm{M})$

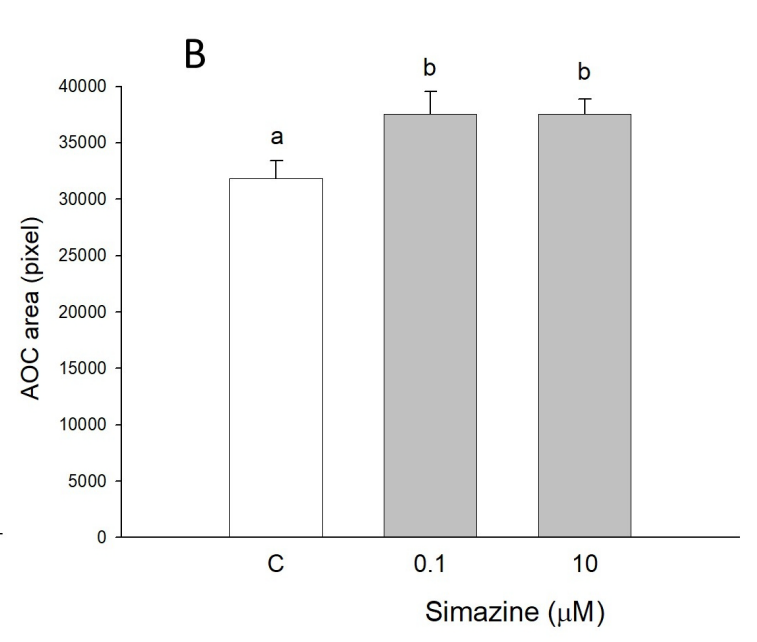

II

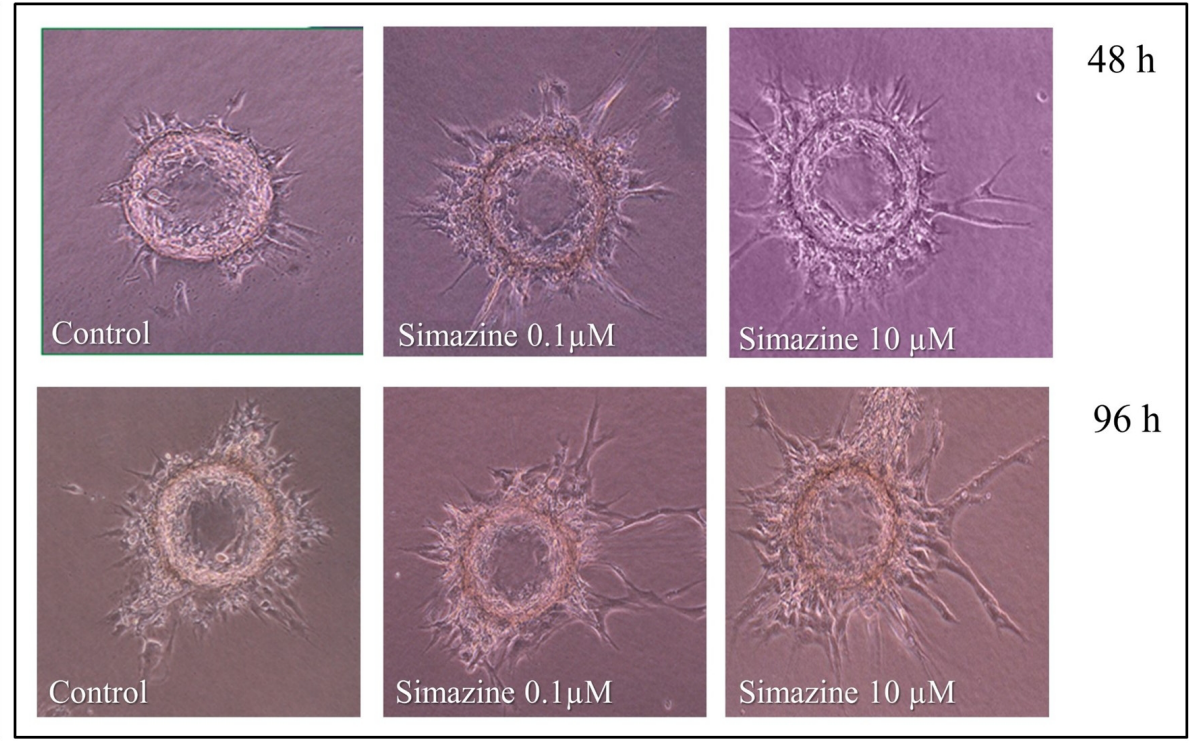

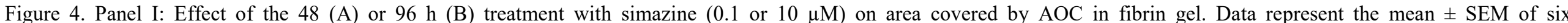

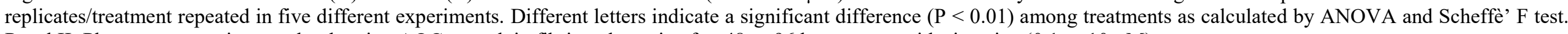
Panel II: Phase contrast micrographs showing AOC growth in fibrin gel matrix after 48 or $96 \mathrm{~h}$ treatment with simazine $(0.1$ or $10 \mu \mathrm{M})$. 


\section{Discussion}

The chlorotriazines (atrazine, simazine, propazine and terbuthylazine) have been widely used as selective herbicides in agricultural crops or as total herbicides in the weed control in railways and roads. Atrazine in particular, is one of the most widely applied herbicides in the United States and it represents the most common water contaminant, having been found in nearly $70 \%$ of all surface and fresh ground water in the United States (Bexfield, 2008). Due to their endocrine disruptor effects and their ubiquitous water contamination, atrazine and simazine use in agriculture has been prohibited in the European Union since 2004. As a consequence of their use in a massive scale, however, in Europe these compounds are still detected in groundwater (Sassine et al., 2016; ISPRA Report 2016) and they remain the most ubiquitous pesticides in aquifers (Loos et al., 2010). Their persistence in the environment for more than 10 years after their ban is a matter of concern for potential adverse health effects in mammalian and aquatic species. In vitro and in vivo studies have documented potential detrimental health effects for atrazine, among which the disruption of the neuroendocrine control of reproductive development and function in many animal species (Cooper et al., 2000; Basini et al., 2012; Forgacs et al., 2013), the induction of mammary gland tumors in the rat (Cooper et al., 2007) and the promotion of prostate cancer cell growth (Hu et al., 2016).

With regard to simazine toxicity by Ren et al. (2013) has documented a possible impairment of immune function of mice orally exposed to simazine, while Stara et al. (2012) demonstrated that chronic exposure to this substance can induce changes redox status in common carp.

Starting from these experimental observations, showing that simazine can impair several different biological mechanisms, here we document that this compound, even at low doses, impairs swine granulosa cell function, possibly resulting in reproductive dysfunction. Rich et al. (2012) reported similar effects on human breast cancer cell lines, hypothesizing an association between simazine stimulatory action on cell growth and the presence of estrogen receptor.

Following a $24 \mathrm{~h}$ exposure of human granulosa cell-derived KGN cells to a wide range of simazine concentrations, Park et al. (2014) reported a biphasic response for cell viability and proliferation; in particular, low concentrations induced a dose-dependent decrease while higher dosages, in the range of those used in the present study, displayed no effect or stimulatory effects.

Extensive literature has been published about atrazine disrupting effects on steroidogenesis in ovarian granulosa and Leydig cells (Basini et al., 2012; Fa et al., 2013; Pogrmic-Majkic et al., 2016); in particular, an atrazine-induced increase of progesterone secretion has been reported in different species (Tinfo et al., 2011; Basini et al., 2012), raising concerns about a possible impairment of reproductive efficiency by atrazine even at low doses. On the contrary, information regarding simazine is scarce and its possible impact on reproductive activity is still far to be elucidated. Our data show that simazine increases progesterone production, while it does not modulate estradiol 17beta levels in cultured granulosa cells. Similar results have been documented by Forgacs et al. (2013), who observed a simazine stimulatory effect on progesterone levels in murine Leydig cells, possibly due to changes in steroidogenic gene expression.

As regards to simazine possible modulatory action on estradiol 17beta production, a simazineinduced increase of aromatase has been documented in human adrenocortical carcinoma cell lines (Fan et al. 2007; Sanderson et al., 2001). According to our present data, we cannot confirm the disrupting effects of simazine at micromolar range on estradiol production by swine granulosa cells, and thus its possible modulatory action should be further tested at higher dosages in the same in vitro model.

In previous works (Basini et al., 2012) we have documented that atrazine, at dosages similar to those considered in the present work, can interfere with the angiogenic process within the ovarian follicles, in particular affecting the production of the main angiogenesis signaling molecules VEGF and NO.

Conversely to the observations of Park et al. (2016) about simazine suppressive effect on NO production in human granulosa cells, in our experiment this molecule appeared ineffective in modulating NO levels, while significantly enhanced AOC growth in the in vitro angiogenesis bioassay. The present results lead us to hypothesize that also simazine can be possibly qualified as a pro-angiogenic molecule, as already suggested for different endocrine disruptors (Grasselli et al., 2010; Durando et al., 2011; Basini et al., 2012). Further studies are needed to better investigate about its potential modulatory effect on VEGF production, thus confirming this hypothesis.

\section{References}

Basini G, Bussolati S, Santini S, Bianchi F, Careri M, Mangia A, Musci M, Grasselli F. 2008. Hydroxyestrogens inhibit angiogenesis in swine ovarian follicles. J Endocrinol, 199: 127-135.

Basini G, Bianchi F, Bussolati S, Baioni L, Ramoni R, Grolli S, Conti V, Bianchi F, Grasselli F. 2012. Atrazine disrupts steroidogenesis, VEGF and NO production in swine granulosa cells. Ecotoxicol Environ Saf, 85:59-63.

Basini G, Tamanini C. 2000. Selenium stimulates estradiol production in bovine granulosa cells: possible involvement of nitric oxide. Domest Anim Endocrinol, 18(1):1-17

Basini G, Bussolati S, Grolli S, Ramoni R, Grasselli F. 2016. Bisphenol A interferes with swine vascular endothelial cell functions. Can J Physiol Pharmacol, 20:1-7.

Bexfield LM. 2008. Decadal-scale changes of pesticides in ground water of the United States, 19932003. J Environ Qual, 37(Suppl.5):S226-39.

Breckenridge CB, Campbell JL, Clewell HJ, 
Andersen ME, Valdez-Flores C, Sielken RL Jr. 2016. PBPK-based Probabilistic Risk Assessment for Total Chlorotriazines in Drinking Water. Toxicol Sci, 150(2):269-282.

Commission of the European Communities. 2004a. Commission Decision of 10 March 2004 concerning the non-inclusion of simazine in Annex I to Council Directive 91/414/EEC and the withdrawal of authorisations for plant protection products containing this active substance (2004/247/EC). Off J Eur Union, L78:50-52.

Commission of the European Communities. 2004b. Commission Decision of 10 March 2004 concerning the non-inclusion of atrazine in Annex I to Council Directive 91/414/EEC and the withdrawal of authorisations for plant protection products containing this active substance (2004/248/EC). Off J Eur Union, L78: 53-55.

Cooper RL, Stoker TE, Tyrey L, Goldman JM, McElroy WK. 2000. Atrazine disrupts the hypothalamic control of pituitary-ovarian function. Toxicol Sci, 53(2):297-307.

Cooper RL, Laws SC, Das PC, Narotsky MG, Goldman JM, Lee Tyrey E, Stoker TE. 2007. Atrazine and reproductive function: mode and mechanism of action studies. Birth Defects Res B Dev Reprod Toxico, 80(2):98-112.

Dong YL, Yallampalli C. 1996. Interaction between nitric oxide and prostaglandin E2 pathways in pregnant rat uteri. Am J Physiol, 270(3 Pt 1):E471-6.

Durando M, Kass L, Perdomo V, Bosquiazzo VL, Luque EH, Muñoz-de-Toro M. 2011. Prenatal exposure to bisphenol A promotes angiogenesis and alters steroid-mediated responses in the mammary glands of cycling rats. J Steroid Biochem Mol Biol, 1 27(1-2):35-43.

European Parliament and Council of the European Union. 2001. Decision No 2455/2001/EC of the European Parliament and of the Council of 20 November 2001 establishing the list of priority substances in the field of water policy and amending Directive 2000/60/EC. Off J Eur Communities, L331: 0001-0005.

Fa S, Pogrmic-Majkic K, Samardzija D, Glisic B, Kaisarevic S, Kovacevic R, Andric N. 2013 Involvement of ERK1/2 signaling pathway in atrazine action on FSH-stimulated LHR and CYP19A1 expression in rat granulosa cells. Toxicol Appl Pharmacol, 270(1):1-8.

Fan W, Yanase T, Morinaga $H$, Gondo S, Okabe T, Nomura M, Komatsu T, Morohashi K, Hayes TB, Takayanagi R, Nawata H. 2007. Atrazine-induced aromatase expression is SF-1 dependent: implications for endocrine disruption in wildlife and reproductive cancers in humans. Environ Health Perspect, 115(5):720-727.

Forgacs AL, D'Souza ML, Huhtaniemi IT, Rahman NA, Zacharewski TR. 2013. Triazine herbicides and their chlorometabolites alter steroidogenesis in BLTK1 murine Leydig cells. Toxicol Sci, 134(1):155-167.

Fuhrman BJ, Schairer C, Gail MH, Boyd-Morin J, Xu X, Sue LY, Buys SS, Isaacs C, Keefer LK,
Veenstra TD, Berg CD, Hoover RN, Ziegler RG. 2012. Estrogen metabolism and risk of breast cancer in postmenopausal women. $J$ Natl Cancer Inst, 104(4):326-339.

Grasselli F, Basini G, Tirelli M, Cavalli V, Bussolati S, Tamanini C. 2003.Angiogenic activity of porcine granulosa cells co-cultured with endothelial cells in a microcarrier-based three-dimensional fibrin gel. $J$ Physiol Pharmacol, 54:361-370.

Grasselli F, Baratta M, Tamanini C. 1993. Effects of a GnRH analogue (buserelin) infused via osmotic minipumps on pituitary and ovarian activity of prepuberal heifers. Anim Reprod, 32:153-161.

Grasselli F, Baratta L, Baioni L, Bussolati S, Ramoni R, Grolli S, Basini G. 2010. Bisphenol A disrupts granulosa cell function. Domest Anim Endocrinol, 39(1):34-39.

Hu K, Tian Y, Du Y, Huang L, Chen J, Li N, Liu W, Liang Z, Zhao L. 2016. Atrazine promotes RM1 prostate cancer cell proliferation by activating STAT3 signaling. Int J Oncol, 48(5):2166-2174.

Istituto Superiore per la Protezione e la Ricerca Ambientale (ISPRA). 2016. Rapporto nazionale pesticidi nelle acque. Available in: http://www.isprambiente.gov.it.

Loos R, Locoro G, Comero S, Contini S, Schwesig D, Werres $F$, Balsaa $P$, Gans $O$, Weiss $S$, Blaha $L$, Bolchi M, Gawlik BM. 2010. Pan-European survey on the occurrence of selected polar organic persistent pollutants in ground water. Water Res, 44:4115-4126.

Park S, Kim S, Jin H, Lee K, Bae J. 2014. Impaired development of female mouse offspring maternally exposed to simazine. Environ Toxicol Pharmacol, 38(3):845-51.

Park SE, Lim SR, Choi HK, Bae J. 2016. Triazine herbicides inhibit relaxin signaling and disrupt nitric oxide homeostasis. Toxicol Appl Pharmacol, 15, 307:10-8

Pogrmic-Majkic K, Fa S, Samardzija D, Hrubik J, Kaisarevic S, Andric N. 2016. Atrazine activates multiple signaling pathways enhancing the rapid hCGinduced androgenesis in rat Leydig cells. Toxicology, 10, 368-369:37-45.

Qian HF, Takuma T, Tsuyoshi E, Fumihiko S. 2014. The PGR5 and NDH pathways in photosynthetic cyclic electron transfer respond differently to sub-lethal treatment with photosystem-interfering herbicides. $J$ Agric Food Chem, 62:4083-4089.

Ren R, Sun DJ, Yan H, Wu YP, Zhang Y. 2013. Oral exposure to the herbicide simazine induces mouse spleen immunotoxicity and immune cell apoptosis. Toxicol Pathol, 1(1):63-72.

Rich JD, Gabriel SM, Schultz-Norton JR. 2012. In vitro effects of herbicides and insecticides on human breast cells. ISRN Toxicol, 14: 232461.

Sai L, Liu Y, Qu B, Yu G, Guo Q, Bo C, Xie L, Jia Q, Li Y, Li X, Ng JC, Peng C. 2015. The Effects of Simazine, a Chlorotriazine Herbicide, on the Expression of Genes in Developing MaleXenopus laevis. Bull Environ Contam Toxicol, 95(2):157-63.

Sanderson JT, Letcher RJ, Heneweer M, Giesy JP, van den Berg M. 2001. Effects of chloro-s-triazine 
herbicides and metabolites on aromatase activity in various human cell lines and on vitellogenin production in male carp hepatocytes. Environ Health Perspect, 109(10):1027-31.

Sassine L, Le Gal La Salle C, Khaska M, Verdoux P, Meffre P, Benfodda Z, Roig B. 2016. Spatial distribution of triazine residues in a shallow alluvial aquifer linked to groundwater residence time. Environ Sci Pollut Res Int, (8):6878-6888. Doi: 10.1007/s11356016-7224-x.

Stara A, Machova J, Velisek J. 2012. Effect of chronic exposure to simazine on oxidative stress and antioxidant response in common carp (Cyprinus carpio L.). Environ Toxicol Pharmacol, 33(2):334-43.

Stevens JT, Breckenridge CB, Wetzel LT, Gillis JH, Luempert LG 3rd, Eldridge JC. 1994. Hypothesis for mammary tumorigenesis in Sprague-Dawley rats exposed to certain triazine herbicides. J Toxicol Environ Health, 43(2):139-53.
Thurman EM, Goolsby DA, Meyer MT, Mills MS, Pomes ML, Kolpin DW. 1992. A reconnaissance study of herbicides and their metabolites in surface water of the Midwestern United States using immunoassay and gas chromatography/mass spectrometry. Environ Sci Tech, 26:2440-2447.

Tinfo NS, Hotchkiss MG, Buckalew AR, Zorrilla LM, Cooper RL, Laws SC. 2011. Understanding the effects of atrazine on steroidogenesis in rat granulosa and H295R adrenal cortical carcinoma cells. Reprod Toxicol, 31(2):184-193.

United States Environmental Protection Agency (USEPA). 2006. Triazine Cumulative Risk Assessment. Office of Prevention, Pesticides and Toxic Substances, Washington, DC. Federal Register March, 2006, pp.1-65. Zorrilla LM, Gibson EK, Stoker TE. 2010. The effects of simazine, a chlorotriazine herbicide, on pubertal development in the female Wistar rat. Reprod Toxicol, 29(4):393-400. 